Article

\title{
Does corporate reputation matter in the relationship between organizational cultural intelligence and customer loyalty among SMEs in Nigeria?
}

\author{
Joy Sewuese Akpi ${ }^{1 *}$, Linus Jonathan Vem ${ }^{2}$, and Patrick Ojei Eshue ${ }^{3}$ \\ ${ }^{1}$ Faculty of Management Sciences, University of Jos, Plateau State, Nigeria; joysewuese@yahoo.ca \\ ${ }^{2}$ Faculty of Management Sciences, University of Jos, Plateau State, Nigeria; veml@unijos.edu.ng \\ ${ }^{3}$ Floor mills of Nigeria Plc, Golden Penny Place, Apapa Lagos ; pojie@fmnplc.com \\ * Corresponding author.
}

Received: 29 November 2019; Accepted: 27 March 2020; Published: 9 April 2020

\begin{abstract}
The declined customer loyalty and low competitive spirit confronting Nigerian owned SMEs when compared to their foreign counterparts operating under the same business environment have been an issue of concern for scholars and practitioners. The main thrust of this study is to evaluate the role of organizational cultural intelligence and corporate reputation on customer loyalty. A survey questionnaire was retrieved from 250 businesses owned by Nigerian (other than the natives of the place of operation) and Non-Nigerians operating in Plateau State Nigeria, and from 335 customers of these businesses as well. The data collected was analyzed using Smart-PLS 3.2.7 Software to determine the direct relationship between Organisational Cultural Intelligence and Customer loyalty and the indirect relationship through the intervening role of corporate reputation. The results revealed the relationship between organizational cultural intelligence and customer loyalty as positive but insignificant. While corporate reputation mediates the relationship between organizational cultural intelligence and customer loyalty. We further discussed the theoretical and practical implications as well as a recommendation for future studies. We inferred that Organisational CQ and Corporate reputations are important predictors and mechanisms to understanding customer loyalty among SMEs in Nigeria.
\end{abstract}

Keywords: organizational cultural intelligence, corporate reputation, customer loyalty.

JEL codes: M1, M3, M14

\section{Introduction}

Globally, Small and Medium Enterprises (SMEs) are agents of economic growth (Tom, Glory, \& Alfred, 2016), hence it is impossible for any country that is desirous of development to ignore their contribution. This is evident in their response to societal needs and wellbeing, through the production of goods and services, hence resulting in enhancing employment opportunities. A cursory survey on the contribution of SMEs in developed clime like the UK reveals that they accounted for $99 \%$ of all private sector businesses with a turnover of $47 \%$. In terms of employment opportunities, it was reported that $60 \%$ is attributed to their activities annually (Ingirige \& Wedawatta, 2018; de Jesus Pacheco, ten Caten, Jung, Navas, \& Cruz-Machado, 2018).

Coming to Nigeria however, SMEs' performance is grossly incomparable to the successes recorded in developed economies. Though SMEs are potential agents of economic growth and development, their survival and contribution have been unimpressive in Nigeria. For example, the mortality rate of SMEs in Nigeria is as high as $70 \%$ within the first five years of their establishment 
(Idemobi, 2012), suggesting an inability to compete. A report from the United Nations Industrial Development Organization's Investment and Technology Promotion office in Nigeria (2017) reveals that only $20 \%$ of SMEs established in Nigeria manage to survive. A Central Bank of Nigeria report 2020 indicates that, though SMEs in Nigeria posted 47\% to GDP in 2019, Nigerian owned businesses contributed only 7\% to export. In addition, a World Economic Forum report (2018) reveals a steady decline in the ability of Nigerian companies to compete despite the potential success factors that abound. The competitive indicators nose-dived from 3.81\% in 2009 to $3.3 \%$ in 2018, this justifies the claim by Azmat and Huong (2013) that businesses in developing countries are yielding to the aggressive marketing activities of the foreign-owned companies operating within their domain. This challenged social identity assumption (Tajfel, 1978) on shared identity and cultural unison that triggers solidarity and citizen's sentiments in stimulating loyalty behavior towards local SMEs. We are therefore concerned about what SMEs in Nigeria must do differently in order to over-turn the customer loyalty challenge confronting the sector.

\subsection{Customer Loyalty in SMEs' Success}

The literature on customer loyalty has been classified into two streams namely, behavioral and attitudinal. Behavioral loyalty is said to occur when a customer purchases a particular product brand frequency (Kandampully \& Zhang, 2015). Critics have floored that definition on the basis of its limitations in distinguishing between commitment and convenience hence, preferred attitudinal loyalty. On the flip side, attitudinal loyalty is defined as, "a deeply held commitment to patronize a preferred product or service consistently in the future, despite situational influences and marketing efforts having the potential to cause switching behavior" (Oliver, 1997:392). Unlike behavioral loyalty which is based on the frequency of purchase, attitudinal loyalty occurs on the basis of commitment and preference despite alternatives, which is the foundation of this study.

Customer loyalty has been widely debated over the past decades as one critical success factor in relationship marketing (Hallowell, 1996; Gruen, Osmonbekov, \& Czaplewski, 2006; So, King, Sparks, \& Wang, 2016; Wang et al., 2017) and central to firm's survival. Dick and Basu (1994) consider it germane and the thrust of the marketing strategy. That is, within every marketing strategy lies a subtle desire to develop, maintain and enhance trust and lasting patronage in a firm's product and or services. In addition, there has been a growing realization that retaining an existing customer is cheaper than gaining new ones (Xie and Chen 2013 in Hwang \& Mattila, 2018) hence, relationship management is crucial in every business model. In addition, Fara and Huong (2013) and Aksoy (2013) posited that, as competition heightens, businesses fall back on loyal customers for survival. Thus, are willing to pay more, express higher buying behavior and low switching tendency (Evanschitzky et al, 2012; Jay \& Tingting, 2015). Therefore, an SME's ability to thrive is gauged on the ability to innovatively gain the trust and loyalty of their current and would-be customers (Dominici \& Guzzo, 2010). In the same vein, Solnet and Kandampully (2008) opined that building organizational strength on product and service features alone is not enough rather a unique differentiating attribute, in the customer is an important asset for success.

Although a handful of studies have examined the antecedents to customer loyalty over the past decade, from a different point of view yet, high research interest is still growing among researchers. A survey of the literature reveals that extant literature focused on the perception of trust as the antecedent to customer loyalty (Ball, Simões Coelho, \& Machás, 2004; Wah Yap, Ramayah, \& Nushazelin Wan Shahidan, 2012; Martínez \& del Bosque, 2013). Similarly, Customer satisfaction (Cha \& Borchgrevink, 2018; Helm, Eggert, \& Garnefeld, 2010) and corporate reputation (de Leaniz \& del Bosque Rodríguez, 2016; Walsh, Mitchell, Jackson, \& Beatty, 2009) have also been found to predict customer loyalty.

However, this study observed that to date, organizational cultural intelligence (CQ) has not been considered in relationship management as an antecedent to customer loyalty, despite the potential influence on customer purchase behavior. A study has associated organizational (CQ) with crosscultural attributes and competencies in bolstering corporate success in a strategic alliance (Yitmen, 
2013) at an organizational level, however, the relationship with customer loyalty is still is not known. In addition, a further search apparently reveals that CQ is well established at the individual level (Lima, West, Winston, \& Wood, 2016), while a paucity of literature on organizational CQ exists. Furthermore, Lima, West, Winston, and Wood (2016) observed that literature on organizational CQ is sketchy, and noticed that only five articles (Ang and Inkpen, 2008; Chen, Liu, \& Portnoy, 2012; Moon, 2010; Van Driel \& Gabrenya Jr, 2013; Yitmen, 2013), represent the published research on CQ at the organizational level. This makes the literature that integrates the same as intended with customer relationship management even scarce. In addition, we also seek to establish the mechanism that will integrate the association between organizational CQ and customer loyalty. We expect corporate reputation to explain the antecedent role of Organizational CQ on customer loyalty on the ground that a culturally intelligent organization has the advantage of penetrating boundaries to connect with stakeholders. This capability is expected to create a positive image that stimulates loyalty. Again, a search on the intervening role of customer corporate reputation between organizational CQ on customer loyalty reveals a dearth of literature.

\subsection{Organizational Cultural Intelligence}

Cultural intelligence in an organization is the capability to function effectively in a culturally diverse environment with the aim of competing as well as developing a sustainable strategy in crosscultural interaction. Lima et al., (2016) in line with Ang and Inkpen (2008) operationalized Organizational CQ as a function of; (i) leadership behavior towards others culture, (ii) adaptability, (iii) training on intercultural interaction, (iv) intensity and (v) inclusiveness.

Leadership behavior; is synonymous with managerial CQ (Nelson, 1996; Kanfer \& Heggestad, 1997; Hall, 1959) focuses on managers and employee CQ as an embodiment of the vision and image that portrays organizations to the society, their understanding, motivation, and behavior. Their metacognitive and cognitive perception (Nelson, 1996; Ang et al., 2006; Ang and Inkpen 2008; Lima et al., 2016), motivation (Kanfer \& Heggestad, 1997) and salient language or behavior (Hall, 1959; Ang and Inkpen 2008) in a cross-cultural interaction portray the image of the organization as embodied in its core values.

Adaptability; as s dimension focuses on programs that are culturally sensitive and tailored to cultural group's tradition with the view of making adjustment (Castro, Barrera Jr., \& Martinez Jr., 2004) in order to address the core values, beliefs, norms, and other important aspects of the cultural group's worldviews and lifestyles. In the context of this study, SMEs operating outside of their cultural setting are expected to learn the art of aligning their identity with the host community in order to attract their loyalty.

Training; Lima et al. (2016) established as critical the role of training as a dimension which seeks to position organizations as culturally intelligent. They posit that organizations that desire growth in their level of CQ must not pay lip-service to leadership development and training. Here, training that is centered on multi-cultural interaction is helpful in inculcating leadership and adaptability.

Intentionality; focuses on the ability to articulating values that are consistent with CQ and is a significant way of cultivating organizational CQ. Here key leaders ask for feedback after communication across culture as well as monitor cross-cultural interaction. In addition, intentionality entails deliberate use of language that is inclusive.

Inclusiveness; explains how a culturally intelligent firm desire mutual integration with the internal and external community (Lima, et al., 2016). This is demonstrated through granting of equal opportunity to employees regardless of their diverse affiliation. Similarly, inclusiveness can be demonstrated through the use of diverse voices in strategic communication, as well as showing an understanding of the ever-changing nature of diversity.

This study tests the antecedent role of organizational CQ and the intervening role of corporate reputation in predicting customer loyalty among businesses and customers in Plateau State Nigeria. 


\subsection{Conceptual Review and Hypotheses Development}

This study proposes a perspective of understanding customer loyalty to an organization through the predictive specs of Organizational Cultural Intelligence (CQ). In addition, we proposed a mechanism through Corporate Reputation (CR) to explain why the relationship should exist. Based on the logic in the conceptualization, Organizational Cultural Intelligence (CQ) should directly or indirectly impact customer loyalty, with customer perception of corporate reputation mediating the relationship as depicted in Figure 1.

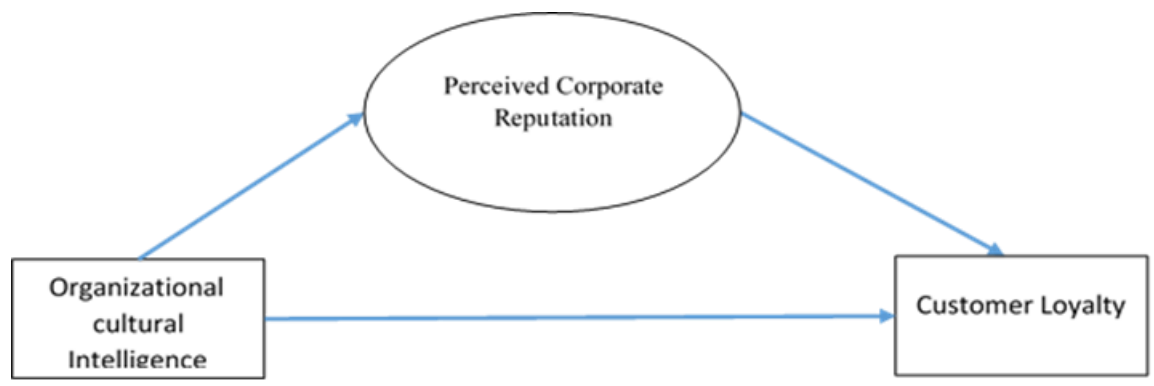

Figure 1. Conceptual Framework

\subsection{Antecedent Role of Organizational Cultural Intelligence}

As established, organizational CQ is the ability of an organization to configure its capability in order to function effectively in a culturally diverse environment, with the aim of taking advantage as well as sustaining its corporate objective. Since businesses often operate outside their domain of cultural advantage, (Chen, Liu, \& Portnoy, 2012) emphasis on this capability should be central to every business strategy.

Because of its relative newness in the organizational literature, empirical evidence relating organizational CQ and any marketing outcome are rare. However, literature abounds on cultural intelligence at an individual level relating to other factors such as adaptive selling behavior (Charoensukmongkol, 2019), interaction involvement (Puyod \& Charoensukmongkol, 2019). Thus, we leveraged on Social Identity Theory (SIT) (Billig \& Tajfel, 1973; Tajfel, 1978) and Social exchange theory (SET) to push further our argument in this study. SIT refers to an individual acknowledging her or his belongingness to a certain social group, which significantly influences the person's emotions and values (Miles, 2012). The level of influence on a member is such that they identify and appraise themselves in the same way, ii) share a common view of who they are and what is peculiar to them follow a similar style of interacting with others who are considered non-members of the group (Hogg, 2006; Miles, 2012). Organizations that project managers with positive leadership behavior are able to infiltrate cultural barriers through cultural assimilation and diffusion to a level of societal acceptability. On the flip side is the exchange that comes in the form of reciprocity. An organization capitalizes on its found capability to psychologically solicit for customers loyalty in exchange as explained in Social Exchange Theory ( Blau, 1964; Homans, 1974; Cropanzano \& Mitchel, 2005)

Therefore, we posit that where customers perceive an organization as sensitive and appreciative of their particular way of life, it enhances a positive corporate image and strengthen their loyalty. Consistent with this we hypothesize that;

Hypothesis 1: Organizational cultural Intelligence positively associates with customer loyalty.

Hypothesis 2: Organizational cultural Intelligence positively associates with Customers' perceived corporate reputation.

\subsection{The mediating role of Corporate Reputation}

Corporate reputation has attracted a definitional interest in the management literature (Barnett, Jermier, \& Lafferty, 2006). A survey of the literature grouped existing definitions under three themes 
namely, 1) perception as asset (Wei, Ouyang, \& Chen, 2017; Goldberg, Cohen, \& Fiegenbaum, 2003; Mahon, 2002), 2) what stakeholders assess (Neville, Bell, \& Mengüç, 2005), 3) Awareness about the firm (Larkin, 2002), buttressing the fact that corporate reputation like most concepts in the field of business has attracted divergent opinions. Barnett, Jermier, and Lafferty (2006), and Chun (2005) extended the discussion by classifying corporate reputation into three schools of thought namely, evaluative, impressional and relational schools.

Evaluative view emphasizes organizational achievement thereby perceives reputation as asset (Wei, Ouyang, \& Chen, 2017; Goldberg, Cohen, \& Fiegenbaum, 2003; Mahon, 2002), while impressional school dwells on overall impression by the stakeholders, synonymous to Barnett et al. (2006) assessment classification, where reputation is formed base on others ratings. Relational school of thought, on the other hand, sees corporate reputation from the point of view of the gap between internal and external stakeholders' organizational image. Basically, awareness about the organization as whole counts, hence the relational perspective becomes key to deliberately creating a perfect corporate image that has an indelible impression on the current and prospective stakeholders.

The divergent opinions on corporate reputation underscore the multi-facet outlook of the construct. This is evident in its operationalization as a multi-dimensional construct. This study adopts Walsh, Beatty, and Shiu's (2009) five-dimensions perspective to a customer-based corporate reputation (i.e customer orientation, the good employer, reliable and financially strong, product and service quality, service and environmental responsibility). All these dimensions put together shape customers' perception of what an organization represents.

Understanding corporate reputation from perceivers' (customers) perspective is expected explains the critical roles it plays between organizational cultural intelligence and customer loyalty. As observed, though organizational cultural intelligence is relatively new, scanty literature exists, but at the individual level CQ has been found to associate positively with organizational outcomes. In Kadam, Rao, Abdul, and Jabeen (2019) CQ of the SME owner was found to predict firm performance (FP). Similarly, de la Garza Carranza and Egri (2010) found managerial cultural intelligence to significantly influence organizational effectiveness. Thus we expect organizational cultural intelligence to influence corporate reputation. On the flip side, the relationship between corporate reputation and customer loyalty is well established (Helm \& Tolsdorf, 2013; Lai, 2019). For example, Gul (2014), discovered that the good reputation of a company affects customer loyalty. Hence we expect SME's reputation to influence their customer loyalty.

The customer-based corporate reputation in this study provides a mechanism through which the proposed relationship should hold sway. Studies have found corporate reputation to mediate the relationship between organizational strategies and customer loyalty. For example, in Aramburu and Pescador's (2019) corporate reputation was found to mediate the relationship between corporate social responsibility and customer loyalty. It was also found to mediate the relationship between service innovation and cross-buying intention (Sridhar \& Mehta, 2018). It is on these bases that we expect it to mediate the relationship between organizational CQ being a corporate strategy and customer loyalty.

Our contention for the mediating role is persuaded in image theory (Beach \& Mitchell, 1978; Mitchell \& Beach, 1990) which posits that individual has many reasons for expressing their loyalty to an organization. This consequently influences the kind of decision an individual makes. In line with image theory's fundamental assumptions, three kinds of images shape individual's decision: (i) the value image (shaped by individual's personal values); (ii) the trajectory image (which focuses on individual's ideal self); and (3) the strategic image (which dwells on actions an individual takes to be that ideal self), we posit that individuals search for possibilities that enable them to actualize the most returns or satisfaction in their quest for ideal self. Once a fit is entrenched they are motivated to maintain that situation (Miles, 2012).

Riding on this theory, we contend that customers' perception of corporate image in terms of; customer orientation, good employer, reliable and financially strong, product and service quality, service and environmental responsibility (Walsh et al., 2009; Walsh, Bartikowski, \& Beatty, 2012) increases their loyalty to the Organization. Where an individual perceives a positive value image or 
in terms of their potential to add value to their quality of life (Miles, 2012; Mitchell \& Beach, 1990) s/he responds through loyalty to the organization. We, therefore, hypothesize that:

Hypothesis 3: Corporate reputation associate positively with Customer loyalty.

Hypothesis 4: Perceived corporate reputation mediates the relationship between Organizational CQ and customer loyalty.

\section{Data and Methods}

\subsection{Data and Sample}

This study adopted a cross-sectional approach, and the data for the study were drawn from two different sources. First, data regarding organizational CQ was obtained from selected SMEs owned by foreign nationals and Nigerians who are not citizens of Plateau State, North-central Nigeria but are registered and operating within the state. Second, data related to customer-based corporate reputation and loyalty was obtained from customers/clients of these SMEs. For the participating organizations, we considered the entire population of SMEs that are owned by foreigners and non-indigenes of Plateau State. The sample size determination formula by Cochran (1977) was used to arrive at a sample of 394 for the customers. Our preference for this formula is because the population of the current customer base of the SMEs is unknown. In selecting the SMEs we relied on the record obtained from the revenue agency (Plateau State Internal Revenue Service) and company registrar (Corporate Affairs Commission). In all, a population of 250 SMEs was used in the study. Each participating company served as a proxy to locate the customers. A total of 600 copies of the questionnaire were administered to customers using systematic random sampling based on arrival interval of five (5 $\left.5^{\text {th }}\right)$. Out of the 600 copies distributed, 388 were retrieved indicating a $64.7 \%$ response rate. A total of 354 and 235 of the retrieved copies of the questionnaire from the customers and the SMEs respectively were properly filled and found usable for further analyses.

Data used in this study was obtained through a self-response questionnaire administered to the selected SMEs and their customers. Though this method has been criticized for its potential bias on research outcome (Podsakoff, MacKenzie, Lee, \& Podsakoff, 2003), we avoided this tendency procedurally (Chang, Van Witteloostuijn, \& Eden, 2010) by ensuring that we eliminated across measures or similarities in the structure or wording of items such that similarities in meaning are minimized (Podsakoff, Mackenzie, \& Podsakoff, 2012). Similarly, to avoid issues related to consistency motifs, idiosyncratic implicit theories, social desirability tendencies, items used are muddled (Podsakoff et al., 2012; Chang, Van Witteloostuijn, \& Eden, 2010). And lastly, since data is obtained from two different sources, a tendency of common method biases is reduced to the minimum.

\subsection{Measures}

The predicting variable in the study, Organizational CQ was measured using a multidimensional measure adopted by Lima et al. (2016). Organizational CQ is a 5-dimensional variable with Cronbach Alpha of above 0.7 each. These include; leadership behavior $(\alpha=0.86)$, adaptability $(\alpha=0.83)$, training $(\alpha=0.88)$, intentionality $(\alpha=0.76)$ and inclusiveness $(\alpha=0.77)$ measured using 21 items, which required organizations to rate their level cultural intelligence on a 5-point response scale ranging from 1 (strongly disagree) to 5 (strongly agree). Samples of questionnaire items obtained from each dimension are thus; Leadership behavior "Key leaders modify their nonverbal behavior (gestures, time, and space orientation) when a cross-cultural interaction requires it", Adaptability "Key leaders have had extensive international experience" Training "Key leaders have had extensive international experience" Intensity "The organization intentionally monitors its cross-cultural interactions" Inclusiveness "The organization is inclusive. It gives equal opportunity to employees regardless of gender, ethnicity, and so on"

In measuring customer-based corporate reputation we adopted a 5-dimensional scale, consisting of 15-items of 3 per dimension as used in Walsh et al. (2012). The dimensions, Cronbach Alpha and sample items are as thus: Customer orientation $(\alpha=0.81)$ "Has employees who treat customers 
courteously" Good employer ( $\alpha=0.79)$ "Organization is known to have management who pay much attention to the needs of its employees", Reliable and financially strong Company ( $\alpha=0.77)$ "This company in my opinion clearly outperforms competitors always", Product and Services $(\alpha=0.79)$ "This company offers high-quality products and services" and Social and environmental responsibility $(\alpha=0.85)$ "This company can reduce its profits to ensure a clean environment". Items were measured on a 5-point Likert-typed scale.

For the outcome variable, we adopted the measure developed by Narayandas (1996) to assess the level of loyalty among customers of the organizations. The scale was developed as a uni-dimensional measure which is made of 5-items in all. A sample of the questions include; "I am satisfied with my overall experience with this company", "I have developed a good relationship with this company". The items on the measure were assessed on a 5-point Likert-typed ranging from 1 (strongly disagree) to 5 (strongly agree). Before the adapted scales were used, a pre-test was conducted in line with the recommendation in Hair et al. (2014)

\subsection{Respondent Profiles}

A total of 235 companies provided a usable response to the questionnaire on organizational CQ. Out of these, $40.4 \%$ are in the service sector, $21.3 \%$ are into manufacturing while $38.3 \%$ are into both manufacturing and service provision. Out of these companies, $78.7 \%$ are owned by Nigerians who are doing business outside of their own familiar culture, while $21.3 \%$ are owned by foreign nationals. On the side of the 354 customers who participated in the survey, 27.7\% indicated that they have been loyal to their company within the last five years while $72.3 \%$ said they have been consistently patronizing the companies being studied for more than 5 years.

\section{Results}

We further conducted inferential analyses to test the hypothesized relationships via Smart-PLS version 3.2.7, with the following as expected output. First, the Measurement Model was assessed which is similar to Confirmatory Factor Analysis CFA in CB-SEM (Wai Yee, Hassan, \& Ramayah, 2016), which involves the assessment of Composite reliability, Convergent validity and Discriminant validity (Hair Jr, Hult, Ringle, \& Sarstedt, 2016; Hair, Ringle, \& Sarstedt, 2011). Further to that is the result from the Structural Model which made it possible to estimate the path coefficient as hypothesized, the Coefficient of Determination $\left(\mathrm{R}^{2}\right)$, Predictive relevance $\left(\mathrm{Q}^{2}\right)$, and Effect size $\left(\mathrm{f}^{2}\right)$ (Yeap, Ramayah, \& Soto-Acosta, 2016; Hair Jr, Sarstedt, Hopkins, \&. Kuppelwieser, 2014).

\subsection{Assessment of Measurement Model}

The measurement model was assessed to determine the loading of the indicators as presented in Table 2 to ensure that each indicator correlates with others at the threshold of 0.7 (Hair, Ringle, \& Sarstedt, 2011). Composite reliability was evaluated with the recommendation of Bagozzi and Yi (1988) and Nunally and Bernstein's (1978) criteria in mind. Similarly, Convergent Validity was determined through its proxy, Average Variance Extracted (Hair Jr, Hult, Ringle, \& Sarstedt, 2016; Hair, Ringle, \& Sarstedt, 2011), while discriminant validity was analyzed based on Heterotrait and Monotrait criteria.

The results in Table 1 reveal that all factor loading met the threshold value of at least 0.7 indicating that the constructs loading did not violate the requirement in Hair, Ringle, and Sarstedt (2011). Composite Reliabilities are also higher than the threshold values of 0.7 (Bagozzi \& Yi (1988; Nunnally \& Bernstein 1978). In a similar fashion, it is also established that Average Variance Extracted values for all the constructs are all higher than 0.5 (Hair Jr, Hult, Ringle, \& Sarstedt, 2016; Hair, Ringle, \& Sarstedt, 2011), which indicates that convergent validity requirements are upheld (Hair et al., 2011, Hair et al., 2014). 
Table 1. Results of the Measurement Model

\begin{tabular}{|c|c|c|c|c|c|}
\hline Variables & Dimensions & Indicators & $\begin{array}{c}\text { Factor } \\
\text { Loading }\end{array}$ & CR & AVE \\
\hline \multirow[t]{17}{*}{ Org. Cultural Intelligence } & Inclusiveness & Inclu1 & 0.849 & 0.915 & 0.782 \\
\hline & & Inclu2 & 0.899 & & \\
\hline & & Inclu3 & 0.904 & & \\
\hline & Intention & Intent1 & 0.868 & 0.881 & 0.711 \\
\hline & & Intent2 & 0.842 & & \\
\hline & & Intent3 & 0.818 & & \\
\hline & Leadership & LB1 & 0.876 & 0.898 & 0.689 \\
\hline & & LB2 & 0.848 & & \\
\hline & & LB3 & 0.867 & & \\
\hline & & LB4 & 0.721 & & \\
\hline & Adaptability & Adapt2 & 0.853 & 0.891 & 0.731 \\
\hline & & Adapt3 & 0.873 & & \\
\hline & & Adapt4 & 0.838 & & \\
\hline & Training & Train2 & 0.838 & 0.893 & 0.677 \\
\hline & & Train3 & 0.858 & & \\
\hline & & Train4 & 0.749 & & \\
\hline & & Train6 & 0.843 & & \\
\hline \multirow[t]{27}{*}{ Corporate Reputation } & Customer Orientation & $\mathrm{CO} 1$ & 0.894 & 0.946 & 0.744 \\
\hline & & $\mathrm{CO} 2$ & 0.883 & & \\
\hline & & $\mathrm{CO} 3$ & 0.916 & & \\
\hline & & $\mathrm{CO} 4$ & 0.848 & & \\
\hline & & $\mathrm{CO} 5$ & 0.837 & & \\
\hline & & $\mathrm{CO} 6$ & 0.793 & & \\
\hline & Good Employer & GE1 & 0.828 & 0.940 & 0.723 \\
\hline & & GE2 & 0.884 & & \\
\hline & & GE3 & 0.880 & & \\
\hline & & GE4 & 0.818 & & \\
\hline & & GE5 & 0.802 & & \\
\hline & & GE6 & 0.885 & & \\
\hline & Prod. \& Serv. Quality & PSQ1 & 0.909 & 0.952 & 0.800 \\
\hline & & PSQ2 & 0.912 & & \\
\hline & & PSQ3 & 0.866 & & \\
\hline & & PSQ4 & 0.900 & & \\
\hline & & PSQ5 & 0.883 & & \\
\hline & Reliability \& Financial, Strength & RFSC1 & 0.841 & 0.918 & 0.652 \\
\hline & & RFSC2 & 0.866 & & \\
\hline & & RFSC3 & 0.795 & & \\
\hline & & RFSC4 & 0.743 & & \\
\hline & & RFSC5 & 0.816 & & \\
\hline & & RFSC6 & 0.777 & & \\
\hline & Social \& Env. Responsibility & SER1 & 0.830 & 0.901 & 0.696 \\
\hline & & SER2 & 0.731 & & \\
\hline & & SER3 & 0.878 & & \\
\hline & & SER4 & 0.889 & & \\
\hline \multirow[t]{5}{*}{ Customer Loyalty } & & Loya1 & 0.842 & 0.942 & 0.764 \\
\hline & & Loya2 & 0.898 & & \\
\hline & & Loya3 & 0.902 & & \\
\hline & & Loya4 & 0.867 & & \\
\hline & & Loya5 & 0.860 & & \\
\hline
\end{tabular}




\subsection{Discriminant Validity}

Discriminant validity is assessed to determine the extent to which the constructs are dissimilar (Henseler, Ringle, \& Sarstedt, 2014) in the model via Heterotrait and Monotrait (HTMT) criterion (Henseler et al., 2014). It was demonstrated by Henseler, Ringle, and Sarstedt (2015) that the HTMT criterion is superior to other criteria in a Monte Carlo simulation study, hence the preference in this study. Results in Table 2 indicate that discriminant validity is established among the constructs since all the values fall within the acceptable region of $\leq 0.85$ (Franke \& Sarstedt, 2019).

Table 2. Discriminant Validity, HTMT Criterion

\begin{tabular}{lllll}
\hline & & $\mathbf{1}$ & $\mathbf{2}$ & $\mathbf{3}$ \\
\hline $\mathbf{1}$ & Corporate Reputation & & & \\
$\mathbf{2}$ & Customer Loyalty & 0.849 & & \\
$\mathbf{3}$ & Organisational CQ & 0.565 & 0.56 & \\
\hline
\end{tabular}

\subsection{Assessment of Structural Model}

We assessed the structural model in this study bearing in mind the five-step procedure which recommends the assessment of collinearity issues; path analyses co-efficient; evaluation of coefficient of determination $\left(\mathrm{R}^{2}\right)$; determination of effect size $\mathrm{f}^{2}$; and predictive relevance $\left(\mathrm{Q}^{2}\right)$ (Henseler, Hubona, \& Ray, 2016; Hair Jr et al., 2016; Hair Jr et al., 2014).

In evaluating the path relationship, Organizational CQ and Corporate Reputation are considered as higher-order constructs (HOC) with five dimensions each, analyzed using the TypeI (ReflectiveReflective model) for treating hierarchical latent variable using PLS-SEM (Becker, Klein, \& Wetzels, 2012). In addition, a repeated indicator approach of dealing with HOC (Hair Jr et al., 2016) was used and the result presented in Figure 2.

In evaluating the latent relationships, a 1000 sample of bootstrapping procedure was conducted (Wong, 2013; Hair et al., 2011; Yeap et al., 2016) as presented in Table 3.

First, the structural model fit index was assessed as required in PLS-SEM. Henseler, Hubona and Ray (2016); Hair Jr et al. (2016) with the saturated SRMR as 0.079 and RMS theta 0.114 which are both less than the threshold value of 0.08 and 0.12 respectively the model is considered fit. The coefficient of determination $\mathrm{R}^{2}$ which explains the amount of variance in the endogenous construct as the result of the changes in an exogenous variable (Hair Jr et al., 2016; Henseler, Hubona, \& Ray, 2016) was assessed. In this model, $30.1 \%$ of the change in corporate reputation was influenced by organizational CQ, while $72.3 \%$ of the variance in customer loyalty is explained by both organizational CQ and corporate reputation.

Table 3. Results of Structural Model

\begin{tabular}{|c|c|c|c|c|c|c|c|c|}
\hline Hypotheses & Relationships & $\begin{array}{l}\text { Std } \\
\text { Beta }\end{array}$ & $\begin{array}{c}\text { Std } \\
\text { Error }\end{array}$ & T Stat & Decision & $F^{2}$ & $\mathrm{Q}^{2}$ & VIF \\
\hline HI & ORG. CQ -> CL & 0.094 & 0.067 & 1.404 & Not Supported & 0.022 & & 1.341 \\
\hline $\mathbf{H} 2$ & ORG. CQ -> CR & 0.549 & 0.084 & 6.550 & Supported & 0.431 & 0.168 & 1.000 \\
\hline H3 & CORP REP -> CL & 0.795 & 0.072 & 11.038 & Supported & 1.596 & 0.514 & 1.341 \\
\hline \multicolumn{9}{|c|}{$\begin{array}{c}\text { Model fit SRMR 0.079, } \text { RMSTheta }^{0.114} \mathrm{R}^{2}: 0.723,0.301 \\
\mathrm{R}^{2}: \quad \text { Adjusted: } 0.72,0.297\end{array}$} \\
\hline
\end{tabular}

The relationship in $\mathrm{H} 1$ between organizational CQ and customer loyalty reveals an insignificant relationship as seen in $(\beta=0.094, \mathrm{t}$-value $=1.404)$ since the $\mathrm{t}$-statistics is less than the 1.65 thresholds for a one-tailed test. In the relationship between organizational CQ and corporate reputation assessed in $\mathrm{H} 2$, the result indicates a positive and significant with $(\beta=0.549$, $\mathrm{t}$-value $6.55 \mathrm{~T})$. This implies that for every one standard deviation increase in organizational $C Q$, customer-based corporate reputation 
increases by a standard deviation of 0.549 . Hypothesis three $(\mathrm{H} 3)$ evaluates the relationship between customer-based corporate reputation and customer loyalty and reveals $(\beta=0.795, t$-value $=11.038)$, indicating a positive significant relationship. This implies that for every one standard deviation increase in customer-based corporate reputation, customer loyalty increases by a standard deviation of 0.795 .

Furthermore, the substantive significance was assessed through the effect size $\left(\mathrm{F}^{2}\right)$ and the predictive relevance $\left(\mathrm{Q}^{2}\right)$ (Hair, Sarstedt, Pieper, \& Ringle, 2012). The effect size (F²) was evaluated to determine the impact of exogenous latent constructs on the structural model, in drawing inference on this, we were guided by Cohen (1988) who categorizes the magnitudes as; 0.02 (small), 0.15 (medium), and 0.35 (large). Consistent with this criterion, the effect size $\mathrm{f}^{2}$ of $0.022,0.431$ and 1.596 on Table 3 are considered small and large. Again, we evaluated the Predictive relevance $\left(\mathrm{Q}^{2}\right)$, which explains the relevance of indicators on the structural model through blindfolding analysis (Hair Jr et al., 2016). This is a sample reuse technique which omits a given data point from an indicator of an endogenous variable in a dth pattern in order to estimate the parameter with the remaining data (Henseler et al., 2016; Hair Jr et al., 2016; Yeap et al., 2016; Reinartz, Haenlein, \& Henseler, 2009). The criterion requires that predictive relevance is established when a $\mathrm{Q}^{2}$ value in a given construct is greater than zero (0) (Hair et al., 2011; Wah Yap, Ramayah, \& Nushazelin Wan Shahidan, 2012). Based on the result in Table 3, the $\mathrm{Q}^{2}$ values are greater than 0 , suggesting that the model did not violate the requirement of the criterion.

Table 4. Mediating Role of Corporate Reputation

\begin{tabular}{cccccccc}
\hline Hypothesis & Relationships & $\begin{array}{c}\text { Std } \\
\text { Beta }\end{array}$ & $\begin{array}{c}\text { Std } \\
\text { Error }\end{array}$ & T Stat & LCI & UCI & Decision \\
\hline H4 & ORG. CQ -> CORP REP -> CL & 0.436 & 0.076 & 5.748 & 0.3 & 0.551 & Supported \\
\hline
\end{tabular}

Furthermore, we assessed the intervening role of corporate reputation in the relationship between organizational CQ and customer loyalty drawing from Preacher \& Hayes, (2008) simple mediation and results presented in Table 4 . We earlier proposed corporate reputation as a mechanism that should explain the relationship as hypothesized in H4. Based on the results following the bootstrapping procedure conducted, a mediating relationship exists in accordance with Preacher and Hayes (2008) and Hair Jr et al. (2013; 2017) first and second criteria. The result shows a full mediation (Hair, Hult, Ringle, \& Sarstedt, 2017) since only the indirect relationships are significant with a t-value greater than 1.96. Secondly, zero (0) did not straddle between the upper and the lower class limit, hence suggesting a strong mediating effect (Hair et al, 2013; 2017).

\section{Discussion}

This is concerned about the challenges confronting Nigerian owned SMEs compared with their foreign counterparts operating in Nigeria. Despite the potential success indicators at their disposal, pieces of evidence available shows otherwise. This study sued for organizational cultural intelligence (CQ) as an antecedent to relationship management with customers. In addition, we explored the role of customer-based corporate reputation as the mechanism of the relationship.

In line with the result, the relationship between organizational CQ and customer loyalty was unexpectedly insignificant. This result is inconsistent with related studies on the influence of individual CQ on adaptive selling behavior (Charoensukmongkol, 2019) and interaction involvement (Puyod \& Charoensukmongkol, 2019) in which both studies revealed a significant relationship. This implies that in the Nigerian setting, organizational CQ alone does not translate into customer loyalty, thus other factors are involved in explaining the relationship. An organization's ability to adapt to a cross-cultural and inter-cultural environment is not a guaranty to success, but the ability to translate that goodwill into a tangible value to the customer. Perhaps the SMEs in Nigeria need to refocus on the customer and their specific needs to ensure attitudinal loyalty. 
The linkage between Organizational CQ through customer-based corporate reputation and customer loyalty shows a significant indirect relationship. Thus SMEs CQ positively bolsters their reputation in line with related evidence in the literature where CSR influences corporate reputation (Aramburu, \& Pescador, 2019), which in turn affects customer loyalty (Helm \& Tolsdorf, 2013; Lai, 2019). This implies that organizational CQ influences customer loyalty through the mechanism role of customer-based corporate reputation.

The mechanism role is consistent with the work of Aramburu and Pescador (2019) where corporate reputation was found to mediate the relationship between corporate social responsibility and customer loyalty. Thus, the role of corporate reputation as intervening variable agrees with Preacher and Hayes (2008) position of establishing mediation through indirect path. The results show that corporate reputation offers an explanation of the underlying mechanism through which organizational CQ influences customer loyalty. In addition, SMEs with high CQ have the tendency of improving their image positively which in turn attracts customer loyalty over time. That is when SMEs practice cultural inclusiveness and are seen as adapting to the values cherished by the society, they also training their managers on the best way to integrate with the host community and significance of diversity (Lima et al., 2016) such SME will be perceived positively. This no doubt is a lubricant for a smooth relationship.

\subsection{Implications}

As businesses continue the search for a new frontier for investment, the need for orientation and capability to function effectively and penetrate cultural barriers is critical. Hence this study was conceived to engender organizational cultural intelligent construct in relationship management guild and provide insightful direction for practice and future studies.

\subsection{Theoretical Implication}

As earlier mentioned, this study drew inspiration from the call made by Lima et al. (2016) on the novelness of the construct organizational CQ. Though documented pieces of evidence exist on cultural intelligence at the individual level, a survey of literature on organizational CQ (Lima et al., 2016) is grossly under research. In response to this call, this study is among the first seeking to establish the construct (Organizational CQ) within the marketing guild to predict customer loyalty. Our position is shaped by Reichers and Schneider (1990 in Dust \& Greenhaus, 2013) that, constructs evolve through stages of development "introduction and elaboration". At the introduction, stage definitions are solidified. Furthermore, at the elaboration stage, perspectives regarding relationships between phenomena become plentiful (Giacalone \& Jurkiewicz, 2010). Thus, we believe that one potentially useful way to further demonstrate the potency of this growing construct at this stage is to illustrate connections with other established research streams within the management guild. When fully integrated into a different context, a foundation for theoretical development would emerge.

The mediating role of corporate reputation supported the importance of image creation through organizational cultural capabilities, the perception from the stakeholders perspective and its consequences on these decisions. The results buttress the role of corporate image (Beach \& Mitchell, 1978; Mitchell \& Beach, 1990) in the antecedent role of organizational CQ on customer loyalty. In essence, the possession of cross-cultural capability by SMEs will translate to customer loyalty when SMEs' reputation is consistent with the cultural strategies.

\subsection{Practical Implication}

Marketing to a diverse society requires more than the traditional marketing strategies (Vem, Sewuese, \& Nmadu, 2018), the need or SMEs to build up their cross-cultural capability in order to thrive particularly in an emergent economy. As argued earlier, when interacting in a culturally diverse setting SMEs with a high level of CQ stance better chances of success (Lima et al., 2016) compared to those with low CQ. Since cultural intelligence has been established as one of the eight forms of 
intelligence (Gardner, 2000), and since it has been established that training and formal education is the key factor (Narayanasamy, 1999) in sharpening developing one's intelligence, SMEs must not pay lipservice to developing this capability and impressing that among their employee.

Since Corporate reputation was found as a mechanism through which the relationship between organizational CQ and Customer loyalty stance, it will pay-off if SMEs overhaul their image internally and externally. Thus, pay attention to social responsibility (Fombrun, Gardberg, \& Barnett, 2000), relating well with internal customers. It has been established that internal stakeholders are inclined toward companies that create and maintain good workplaces. When employees lose a sense of belonging (Zhu, Lyu, Deng, \& Ye, 2017) in a workplace, psychologically they feel unwanted, this feeling affects the extent to which they relate positively with the host community. Since employees are the interface that connects the organization with its external stakeholders (Vem \& Johnmark, 2012) employees are more likely to commit to long-term involvement as ambassadors of the company (Fombrun, Ponzi, \& Newburry, 2015) giving the organization positive image.

\subsection{Limitations and Directions for Future Research}

This research is not without limitations. First, the study was conducted among SMEs operating in Jos Plateau State Nigeria. Though it is a cosmopolitan city with an attractive weather condition, it is a hinterland state with limited business activities, as such, unable to attract foreign-owned companies as much compared to coastal cities like Lagos Port Harcourt and Calabar. Thus, this limits our access and involvement of these categories of SMEs in the study. Second, the literature on cultural intelligence at the organizational level is limited particularly in the developing countries. This explains the low level of empirical evidence and debate from this clime. In view of this, we recommend that this framework is further tested in a more diverse setting with a concentration of multinational and foreignowned companies in Nigeria to get the feel of how they survive in a multi-cultural and multi-ethnic country like Nigeria.

The relationship between organizational CQ and customer loyalty was unexpectedly insignificant despite the logical argument and sound theoretical backing. Thus, we recommend that future researchers could consider exploring the boundary condition under which the relationship fails to hold. We suggest that individual and organizational stereotypes might influence cultural integration to the extent that organizational CQ dimensions are perceived negatively. Could this provide an explanation for the insignificant relationship? Further studies are needed to unearth the factors and their influence on the model. Similarly, Vem, Sewuese, and Nmadu (2018) observed that where national culture is involved, organizations will have to grapple with trust and confidence in spite of their friendly disposition, due to some sensitive demographic, social factors and nationalistic tendency. Future studies could evaluate the extent to which these factors influence the framework.

\section{Conclusions}

In sum, this study has the main thrust of testing the antecedent role of the construct organizational cultural intelligence developed by Lima et al. (2016) on a customer relationship management outcome, through the mechanism of corporate reputation. The idea was in response to Lima's and colleagues' recommendation that their conceptualization is subjected to empirical investigation. From the results obtained in this study, we established empirically an indirect relationship between organizational CQ and customer loyalty through the intervening role of corporate reputation. We found the results insightful in linking SMEs' cultural capability and their reputation in determining the success of their marketing strategies. In line with these revelations, we unearthed some theoretical as well as practical contributions from the outcome in this study. In addition, we acknowledged the limitations of this study and chided the way forward for future researchers to further extend the discussion.

Author Contributions: Conceptualization of this study was done by LJV and JSA; methodology, LJV; software, LJV; validation, JSA and LJV; formal analysis LJV; investigation, POE; resources, POE; data curation, LJV; writing-original draft preparation, JS; writing-review and editing, LJV; supervision, LJV; project 
administration, JSA and POE; funding acquisition, JSA, LJV and POE. In addition, all authors have read and agreed to the published version of the manuscript.

Funding: This research received no external funding other than the resources mobilized by the authors.

Acknowledgments: We specifically acknowledge the support and cooperation received from the firms that willingly participate in the survey conducted.

Conflicts of Interest: The authors declare no conflict of interest.

\section{References}

Ang, S., Van Dyne, L., \& Koh, C. (2006). Personality correlates of the four-factor model of cultural intelligence. Group E Organization Management, 31(1), 100-123.

Aramburu, I. A., \& Pescador, I. G. (2019). The effects of corporate social responsibility on customer loyalty: The mediating effect of reputation in cooperative banks versus commercial banks in the Basque country. Journal of Business Ethics, 154(3), 701-719.

Bagozzi, R. P., \& Yi, Y. (1988). On the evaluation of structural equation models. Journal of the Academy of Marketing Science, 16(1), 74-94.

Ball, D., Simões Coelho, P., \& Machás, A. (2004). The role of communication and trust in explaining customer loyalty: An extension to the ECSI model. European Journal of Marketing, 38(9/10), 1272-1293.

Barnett, M. L., Jermier, J. M., \& Lafferty, B. A. (2006). Corporate reputation : The definitional landscape abstract. Corporate Reputation Review, 9(1), 26-39. https://doi.org/10.1057/palgrave.crr.1550012

Beach, L. R., \& Mitchell, T. R. (1978). A contingency model for the selection of decision strategies. Academy of Management Review, 3(3), 439-449.

Becker, J. M., Klein, K., \& Wetzels, M. (2012). Hierarchical Latent Variable Models in PLS-SEM: Guidelines for Using Reflective-Formative Type Models. Long Range Planning, 45(5-6), 359-394. https://doi.org/10.1016/j.lrp.2012.10.001

Billig, M., \& Tajfel, H. (1973). Social categorization and similarity in intergroup behavior. European Journal of Social Psychology, 3(1), 27-52.

Blau, P. M. (1964). Exchange and power in social life. Transaction Publishers.

Castro, F. G., Barrera Jr., M., \& Martinez Jr., C. R. (2004). The cultural adaptation of prevention interventions: resolving tensions between fit and fidelity. Prevention Science, 5(1), 41-45.

Cha, J., \& Borchgrevink, C. P. (2018). Customers' perceptions of value and food safety on customer satisfaction and loyalty in restaurant environments: moderating roles of gender and restaurant types. Journal of Quality Assurance in Hospitality $\mathcal{E}$ Tourism, 1-19.

Chang, S.-J., Van Witteloostuijn, A., \& Eden, L. (2010). From the editors: Common method variance in international business research. Journal of International Business Studies, 41(2), 178-184.

Charoensukmongkol, P. (2019). The efficacy of cultural intelligence for adaptive selling behaviors in cross-cultural selling: The moderating effect of trait mindfulness. Journal of Global Marketing, 1-17.

Chen, X.-P., Liu, D., \& Portnoy, R. (2012). A multilevel investigation of motivational cultural intelligence, organizational diversity climate, and cultural sales: evidence from US real estate firms. Journal of Applied Psychology, 97(1), 93.

Chun, R. (2005). Corporate reputation: Meaning and measurement. International Journal of Management Reviews, 7(2), 91-109. https://doi.org/10.1111/j.1468-2370.2005.00109.x

Cropanzano, R. and M. S. M. (2005). Social exchange theory: An interdisciplinary review. Journal of Management, 31(6), 874-900. https://doi.org/10.1177/0149206305279602

de la Garza Carranza, M. T., \& Egri, C. P. (2010). Managerial cultural intelligence and small business in Canada. Management Revue, 21(3), 353-371.

de Leaniz, P. M. G., \& del Bosque Rodríguez, I. R. (2016). Corporate image and reputation as drivers of customer loyalty. Corporate Reputation Review, 19(2), 166-178.

Dick, A. S., \& Basu, K. (1994). Customer Loyalty: Toward an Integrated Conceptual Framework. Journal of the Academy of Marketing Science, 22(2), 99-113. https://doi.org/10.1177/0092070394222001

Dust, S. B., \& Greenhaus, J. H. (2013). Spirituality and the work-home interface: a demands-resources perspective. Journal of Management, Spirituality \& Religion, 10(3), 282-305. 
F. Hair Jr, J., Sarstedt, M., Hopkins, L., \& G. Kuppelwieser, V. (2014). Partial least squares structural equation modeling (PLS-SEM) An emerging tool in business research. European Business Review, 26(2), 106-121.

Fara, Azmat \& Huong, H. (2013). Corporate Social Responsibility, Customer Trust, and Loyalty - Perspectives from a Developing Country. Thunderbird International Business Review, 55(3), 253-270. https://doi.org/10.1002/tie

Fombrun, C. J., Gardberg, N. A., \& Barnett, M. L. (2000). Opportunity platforms and safety nets: Corporate citizenship and reputational risk. Business and Society Review, 105(1), 85-106.

Fombrun, C. J., Ponzi, L. J., \& Newburry, W. (2015). Stakeholder Tracking and Analysis: The RepTrak® System for Measuring Corporate Reputation. Corporate Reputation Review, 18(1), 3-24. https://doi.org/10.1057/crr.2014.21

Fornell, C., \& Larcker, D. F. (1981). Structural equation models with unobservable variables and measurement error: Algebra and statistics. Journal of Marketing Research, 382-388.

Gardner, H. (2000). A Case Against Spiritual Intelligence. International Journal for the Psychology of Religion, 10(1), 27-34. https://doi.org/10.1207/S15327582IJPR1001_3

Giacalone, R. A., \& Jurkiewicz, C. L. (2010). Handbook of workplace spirituality and organizational performance. Armonk. NY: Sharpe.

Goldberg, A. I., Cohen, G., \& Fiegenbaum, A. (2003). Reputation building: Small business strategies for successful venture development. Journal of Small Business Management, 41(2), 168-186.

Gruen, T. W., Osmonbekov, T., \& Czaplewski, A. J. (2006). eWOM: The impact of customer-to-customer online know-how exchange on customer value and loyalty. Journal of Business Research, 59(4), 449-456.

Gul, R. (2014). The relationship between reputation, customer satisfaction, trust, and loyalty. Journal of Public Administration and Governance, 4(3), 368-387.

Hair, Joe F., Ringle, C. M., \& Sarstedt, M. (2011). PLS-SEM: Indeed a Silver Bullet. The Journal of Marketing Theory and Practice, 19(2), 139-152. https://doi.org/10.2753/MTP1069-6679190202

Hair, Joseph F., Sarstedt, M., Pieper, T. M., \& Ringle, C. M. (2012). The Use of Partial Least Squares Structural Equation Modeling in Strategic Management Research: A Review of Past Practices and Recommendations for Future Applications. Long Range Planning, 45(5-6), 320-340. https://doi.org/10.1016/j.lrp.2012.09.008

Hair Jr, J. F., Hult, G. T. M., Ringle, C., \& Sarstedt, M. (2016). A primer on partial least squares structural equation modeling (PLS-SEM). Sage Publications.

Hall, E. T. (1959). The silent language (Vol. 3). Doubleday New York.

Hallowell, R. (1996). The relationships of customer satisfaction, customer loyalty, and profitability: an empirical study. International Journal of Service Industry Management, 7(4), 27-42.

Helm, S., Eggert, A., \& Garnefeld, I. (2010). Modeling the impact of corporate reputation on customer satisfaction and loyalty using partial least squares. In Handbook of partial least squares (pp. 515-534). Springer.

Helm, S., \& Tolsdorf, J. (2013). How does corporate reputation affect customer loyalty in a corporate crisis? Journal of Contingencies and Crisis Management, 21(3), 144-152.

Henseler, J., Hubona, G., \& Ray, P. A. (2016). Using PLS path modeling in new technology research: updated guidelines. Industrial Management \& Data Systems, 116(1), 2-20. https://doi.org/10.1108/IMDS-09-2015-0382

Hogg, M. A. (2006). Contemporary social psychological theories. Social Identity Theory, 111-136.

Homans, G. C. (1974). Social behavior: Its elementary forms. New York: PsycNet.

Hwang, Y. H., \& Mattila, A. S. (2018). Is It My Luck or Loyalty? The Role of Culture on Customer Preferences for Loyalty Reward Types. Journal of Travel Research, 57(6), 769-778. https://doi.org/10.1177/0047287517718353

Jonathan, V. L., \& Johnmark, D. R. (2012). The impact of employee empowerment on customer satisfaction in the Nigerian service organizations (a study of some selected hotels in Jos, plateau state). International Journal of Current Research and Review, 4(19), 37.

Kadam, R., Rao, S., Abdul, W. K., \& Jabeen, S. S. (2019). Impact of cultural intelligence on SME performance. Journal of Organizational Effectiveness: People and Performance, 6(3), 161-185.

Kandampully, J., \& Zhang, T. C. (2015). Customer loyalty : a review and future directions with a special focus on the hospitality industry. International Journal of Contemporary Hospitality Managemen, 27(3), 379-414. https://doi.org/10.1108/IJCHM-03-2014-0151

Kanfer, R., \& Heggestad, E. D. (1997). Motivational traits and skills: A person-centered approach to work motivation. RESEARCH IN ORGANIZATIONAL BEHAVIOR, VOL 19, 1997, 19, 1-56. 
Lai, I. K. W. (2019). Hotel image and reputation on building customer loyalty: An empirical study in Macau. Journal of Hospitality and Tourism Management, 38, 111-121.

Larkin, J. (2002). Strategic reputation risk management. Springer.

Lima, J. E., West, G. R. B., Winston, B. E., \& Wood, J. A. (2016). Measuring organizational cultural intelligence : The development and validation of a scale. International Journal of Cross-Cultural Management, 16(1), 9-31. https://doi.org/10.1177/1470595815615625

Mahon, J. F. (2002). Corporate reputation: Research agenda using strategy and stakeholder literature. Business $\mathcal{E}$ Society, 41(4), 415-445.

Martínez, P., \& del Bosque, I. R. (2013). CSR and customer loyalty: The roles of trust, customer identification with the company and satisfaction. International Journal of Hospitality Management, 35, 89-99.

Miles, J. A. (2012). Management and organization theory: A Jossey-Bass reader (Vol. 9). John Wiley \& Sons.

Mitchell, T. R., \& Beach, L. R. (1990). “... Do I love thee? Let me count...” Toward an understanding of intuitive and automatic decision making. Organizational Behavior and Human Decision Processes, 47(1), 1-20.

Moon, T. (2010). Organizational cultural intelligence: Dynamic capability perspective. Group E Organization Management, 35(4), 456-493.

Narayanasamy, A. (1999). ASSET: a model for actioning spirituality and spiritual care education and training in nursing. Nurse Education Today, 19(4), 274-285. https://doi.org/10.1054/nedt.1999.0637

Nelson, T. O. (1996). Consciousness and metacognition. American Psychologist, 51(2), 102.

Neville, B. A., Bell, S. J., \& Mengüç, B. (2005). Corporate reputation, stakeholders and the social performancefinancial performance relationship. European Journal of Marketing, 39(9/10), 1184-1198.

Nunally, J. C., \& Bernstein, I. H. (1978). Psychometric theory. New York: McGraw-Hill.

Podsakoff, P. M., MacKenzie, S. B., Lee, J.-Y., \& Podsakoff, N. P. (2003). Common method biases in behavioral research: a critical review of the literature and recommended remedies. Journal of Applied Psychology, 88(5), 879.

Podsakoff, P. M., Mackenzie, S. B., \& Podsakoff, N. P. (2012). Sources of Method Bias in Social Science Research and Recommendations on How to Control It. https://doi.org/10.1146/annurev-psych-120710-100452

Preacher, K. J., \& Hayes, A. F. (2008). Asymptotic and resampling strategies for assessing and comparing indirect effects in multiple mediator models. Behavior Research Methods, 40(3), 879-891. https://doi.org/10.3758/BRM.40.3.879

Puyod, J. V., \& Charoensukmongkol, P. (2019). The contribution of cultural intelligence to the interaction involvement and performance of call center agents in cross-cultural communication. Management Research Review.

Reinartz, W., Haenlein, M., \& Henseler, J. (2009). An empirical comparison of the efficacy of covariance-based and variance-based SEM. International Journal of Research in Marketing, 26(4), 332-344.

So, K. K. F., King, C., Sparks, B. A., \& Wang, Y. (2016). The role of customer engagement in building consumer loyalty to tourism brands. Journal of Travel Research, 55(1), 64-78.

Sridhar, M., \& Mehta, A. (2018). The moderating and mediating role of corporate reputation in the link between service innovation and cross-buying intention. Corporate Reputation Review, 21(2), 50-70.

Tajfel, H. (1978). Intergroup behavior. Introducing Social Psychology.-NY: Penguin Books, 401-466.

Van Driel, M., \& Gabrenya Jr, W. K. (2013). Organizational cross-cultural competence: Approaches to measurement. Journal of Cross-Cultural Psychology, 44(6), 874-899.

Vem, L. J., Sewuese, J., \& Nmadu, T.M.,(2018). Organizational Cultural Intelligence, Corporate Reputation, and Customer Loyalty: A conceptual Framework and Propositions. Tax Academy Research Journal. 2(2), 106-123.

Wah Yap, B., Ramayah, T., \& Nushazelin Wan Shahidan, W. (2012). Satisfaction and trust on customer loyalty: a PLS approach. Business Strategy Series, 13(4), 154-167.

Wai Yee, L., Hassan, S. H., \& Ramayah, T. (2016). Sustainability and Philanthropic Awareness in Clothing Disposal Behavior Among Young Malaysian Consumers. SAGE Open, 6(1), 1-10. https://doi.org/10.1177/2158244015625327

Walsh, G., Bartikowski, B., \& Beatty, S. E. (2012). Impact of Customer-based Corporate Reputation on Nonmonetary and Monetary Outcomes: The Roles of Commitment and Service Context Risk. https://doi.org/10.1111/j.1467-8551.2012.00845.x

Walsh, G., Beatty, S. E., \& Shiu, E. M. K. (2009). The customer-based corporate reputation scale: Replication and short form. Journal of Business Research, 62(10), 924-930. https://doi.org/10.1016/j.jbusres.2007.11.018 
Walsh, G., Mitchell, V., Jackson, P. R., \& Beatty, S. E. (2009). Examining the antecedents and consequences of corporate reputation: A customer perspective. British Journal of Management, 20(2), 187-203.

Wang, Z., Singh, S. N., Li, Y. J., Mishra, S., Ambrose, M., \& Biernat, M. (2017). Effects of Employees' Positive Affective Displays on Customer Loyalty Intentions: An Emotions-as-Social-Information Perspective. Academy of Management Journal, 60(1), 109-129.

Wei, J., Ouyang, Z., \& Chen, H. A. (2017). Well Known or Well Liked? The Effects of Corporate Reputation on Firm Value at the Onset of a Corporate Crisis. Strategic Management Journal.

Wong, K. K. (2013). Partial Least Squares Structural Equation Modeling ( PLS-SEM ) Techniques Using SmartPLS. Marketing Bulleting, 24(1), 1-32.

Yeap, J. A. L., Ramayah, T., \& Soto-Acosta, P. (2016). Factors propelling the adoption of m-learning among students in higher education. Electronic Markets, 1-16.

Yitmen, I. (2013). Organizational cultural intelligence: A competitive capability for strategic alliances in the international construction industry. Project Management Journal, 44(4), 5-25.

Zhu, H., Lyu, Y., Deng, X., \& Ye, Y. (2017). Workplace ostracism and proactive customer service performance: A conservation of resources perspective. International Journal of Hospitality Management, 64, 62-72.

(C) 2020 by the authors. This article is an open-access article distributed under the terms and conditions of the Creative Commons Attribution (CC BY) license (http://creativecommons.org/licenses/by/4.0/). 